\title{
The comparative analyses of selected aspects of conservation and management of Vietnam's national parks
}

\author{
Le Thanh An ${ }^{1,2}$, Janusz Markowski', Maciej Bartos'
}

I Department of Biodiversity Studies, Teacher Training and Bioeducation, Faculty of Biology and Environmental Protection, University of Lodz, 1/3 Banacha, 90-237 Lodz, Poland 2 University of Economics, Hue University, 99 Ho Dac Di, Hue City, Vietnam

Corresponding author: Le Thanh An (ltan@hce.edu.vn)

Academic editor: T. Ziegler | Received 22 August 2017 | Accepted 3 January 2018 | Published 25 January 2018

http://zoobank.org/3818424F-BAE4-4C91-A614-E5CB14CBADCB

Citation: An LT, Markowski J, Bartos M (2018) The comparative analyses of selected aspects of conservation and management of Vietnam's national parks. Nature Conservation 25: 1-30. https://doi.org/10.3897/ natureconservation. 25.19973

\begin{abstract}
The national parks in Vietnam are protected areas in the national system of special-use forests created to protect natural resources and biodiversity. In order to improve the effectiveness of management of national parks, the study assesses some current aspects of conservation and management of natural resources with respect to management plans, financial sources, staff, cooperative activities, causes of limited management capacity and threats to natural resources. Out of the total of 30 national parks, six are under the responsibility of the Vietnam Administration of Forestry (VNFOREST) and 24 national parks are managed by provincial authorities. It was found that most of the national parks have updated their management plans. Financial sources of funding for national parks mainly originated from the central and provincial budgets, with an average of $51 \%$ and $76 \%$ respectively. Fifty percent of national parks spent $40-60 \%$ of their total funding on conservation activities. About $85 \%$ of national parks' staff had academic degrees, typically in the fields of forestry, agriculture and fisheries. Biodiversity conservation was considered a priority cooperative action in national parks with scientific institutes. Major causes of a limited management capacity of national parks included human population growth and pressure associated with resources use, lack of funding, limited human and institutional capacity and land use conflict/land grab. Illegal hunting, trapping, poaching and fishing, the illegal wildlife trade, illegal logging and firewood collecting appeared to be the most serious threats to the conservation and management of natural resources. In addition to
\end{abstract}

Copyright LeThanh An et al. This is an open access article distributed under the terms of the Creative Commons Attribution License (CC BY 4.0), which permits unrestricted use, distribution, and reproduction in any medium, provided the original author and source are credited. 
these results, significant differences were found between the VNFOREST and provincial parks in terms of financial sources, staff and the threat of illegal logging and firewood collecting. The authors' findings offer useful information for national park planners and managers, as well as policy makers and researchers in seeking solutions for the sustainable management of natural resources in national parks.

\section{Keywords}

Conservation, financial sources, management, management plan, national parks, staff, Vietnam

\section{Introduction}

National parks (NPs) are the areas established to protect natural biodiversity and the underlying ecological structure, support environmental processes and promote education and recreation (Dudley 2008). The importance of NPs can be illustrated by their rapid growth around the world (e.g. over the last 14 years, their number has increased by over 30\%, reaching 5,436 sites in 2017) (Chape et al. 2003, IUCN and UNEPWCMC 2017). As a symbol of national pride, NPs contribute to preventing the loss of biodiversity, maintaining the natural conditions and beauty of the landscape and ensuring the supply of ecosystem services (Schägner et al. 2016).

In Vietnam, NPs are protected areas in the system of special-use forests (SUFs) which are intended to protect nature, including rare species, forest ecosystems and genetic resources. Other objectives include the protection of landscapes, cultural and historical sites and the provision of recreation and tourism (GoV 2010). The first Vietnamese NP (Cuc Phuong NP) was established in 1962 (Vo Quy et al. 1996). Since then, the number of NPs has increased from 16 (476,621 ha) in 2002 (cited by Rambaldi et al. 2001) to $30(1,077,236$ ha, reaching ca. $3 \%$ of the total land area) in 2012 (Figure 1, MONRE 2014). According to the approved national planning system of SUFs up to 2020, Vietnam will have 34 NPs $(1,166,462$ ha, reaching ca. 49\% of SUFs' land area and $4 \%$ of the total land area) (GoV 2014c). In 2015, the Government of Vietnam merged the two protected areas of the Du Gia Nature Reserve and Khau Ca Species and Habitat Conservation Area into a national park with a total area of 15,006 ha (GoV 2015). The increasing number of NPs supports the conservation and sustainable development of significant natural ecosystems, landscapes, historical and cultural relics and endangered and rare species in the SUFs (GoV 2014c).

Concerning the governance of Vietnam's NPs, several ministries and agencies are involved in the protection process. The Ministry of Agricultural and Rural Development (MARD) and their provincial departments have overall responsibility for managing protected areas. MARD directly administers NPs with special nature conservation status or those with areas extending across more than one province (GoV 2010, 2014b). Other NPs are managed by the Provincial People's Committees (PPCs) and their departments. In addition, each PPC is responsible for establishing and staffing the NP' management boards, as well as allocating the capital and budget for them. The Ministry of Natural Resource and Environment (MONRE) is responsible for undertaking the state management for the biodiversity of protected areas (GoV 2008, 


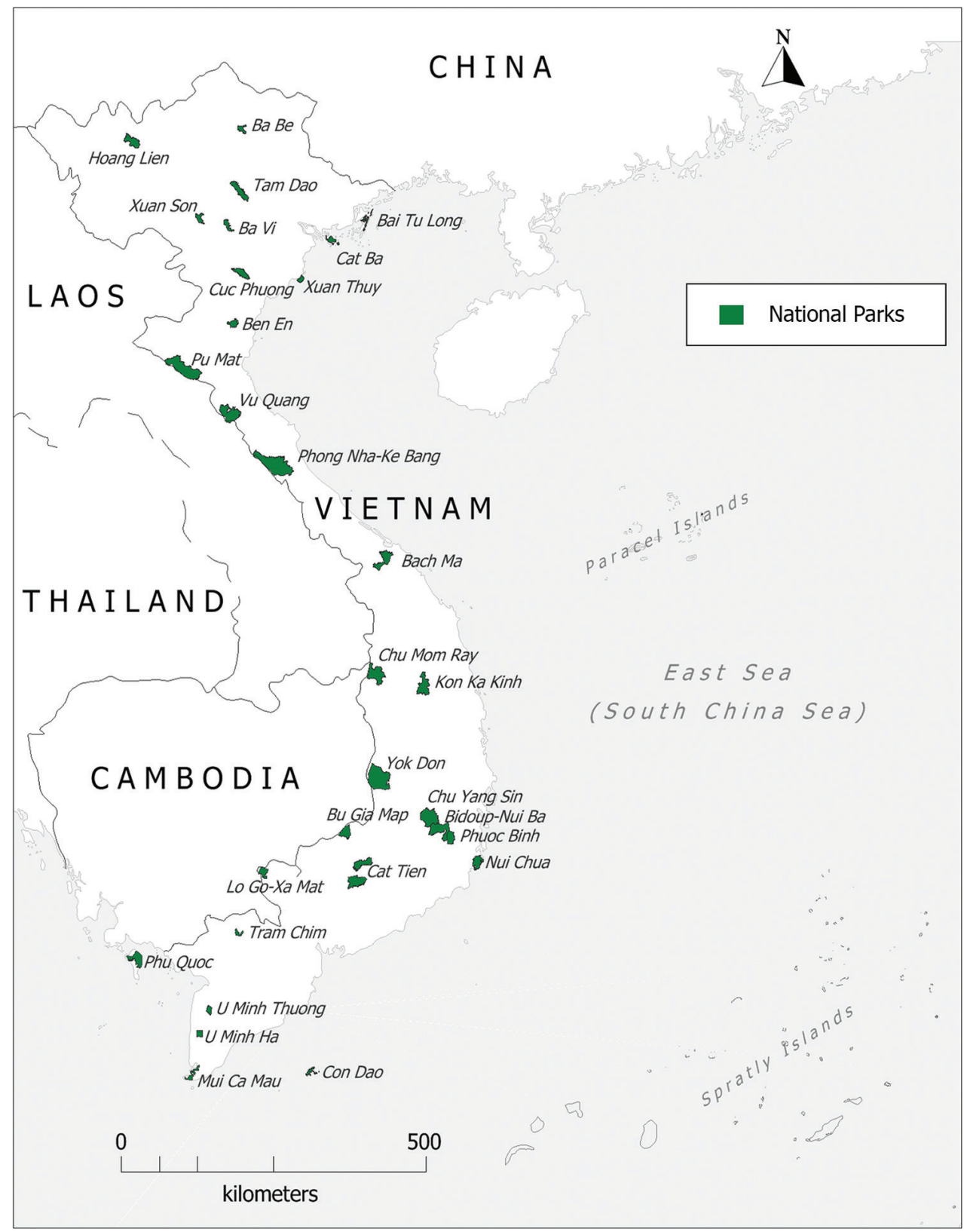

Figure I. Distribution of the thirty national parks, Vietnam. Source: Adapted to IUCN and UNEPWCMC (2017)

2014a). Together with MARD, the Ministry of Culture, Sport and Tourism guides and examines PPCs in the management of eco-tourist activities and promotes NPs as tourism destinations in the development of the tourism sector in Vietnam. However, in the context of the special-use forest system, the management and administration of pro- 
tected areas, including NPs, is fragmented and the division of responsibility between administrative levels is unclear (Nguyen KimDung et al. 2012, VNFOREST 2014).

For the conservation and management of protected areas, NPs suffer from lack of funds, as well as growing investments in infrastructure development (USAID 2013). The funding for protected areas is unstable; it is derived originally from the state budget, but is channelled through central and provincial budgets, international donors and other funding bodies (e.g. ecosystem services) (ICEM 2003, VNFOREST 2014). In some NPs, the central and provincial budgets are just sufficient to cover operations and maintenance costs for protected areas (VNFOREST 2014). The numbers and ability of staff available to manage protected areas are limited, as are those who can engage in biodiversity conservation (MONRE 2014). Most of the leaders and staff in SUFs do not have any specialised knowledge about forests and biodiversity and have not undergone training in conservation skills (MONRE 2014). As a result, building the capacity of the staff plays a crucial role in the effective and efficient management of the protected areas and in achieving conservation objectives.

Despite being ranked as the sixteenth most biodiverse country in the world (Butler 2016), Vietnam faces threats to its biodiversity conservation activities, as well as its protection of natural resources. These issues focus on land conversion, population growth pressure and over-exploitation of natural resources, environmental pollution, climate change and limited human resources (MONRE 2014). In the protected areas of SUFs, VNFOREST (2014) has identified a range of pressures on natural resources, including illegal timber and non-timber forest products, illegal hunting and wildlife trade, grazing in protected areas, land grabbing and tourism.

The aim of this paper is to assess the management and conservation of natural resources in NPs of Vietnam. More specifically, various aspects of NPs were assessed with regard to their management plan, financial sources, staff, cooperative activities, limited management capacity and threats to natural resources. Different groups of NPs were also compared.

\section{Methods}

Surveys and interviews were used for the collection of data related to development and management of national parks in Vietnam. A survey method with a structured questionnaire was sent to management boards directly responsible for national park management in 30 NPs in Vietnam (Figure 1). In order to construct the survey questionnaire properly, a mixed-methods' approach was undertaken: a review of literature determining the context of management of natural resources in Vietnam's protected areas was performed (e.g. ICEM 2003, USAID 2013, MONRE 2014, VNFOREST 2014), followed by discussions with staff and management boards of NPs and then a survey questionnaire was pre-tested with six randomly-selected members of NP management boards.

After pre-testing the questionnaire and submitting comments, a structured questionnaire was developed with a total of 26 questions. This study was part of a wider tourism study in NPs of Vietnam and the survey questionnaire included questions 
focusing on conservation and management of NPs according to the following main subjects of interest: (1) the management plan, (2) financial sources, (3) NP staff (i.e. the number of staff, level of education and education background), (4) cooperative activities in conservation and management of natural resources, (5) causes of limited management capacity of NPs and (6) threats to natural resources (see Appendix 1). In this study, the NP management plan was formulated as a strategic overarching document regarding the management and development of the park in its current and envisaged future forms, in accordance with Thomas and Middleton (2003). The updated status of NPs' management plans was then determined. The perceptions of the respondents concerning limited management capacity and threats to natural resources were rated on a five-point Likert scale ranging from one (strongly disagree) to five (strongly agree) with a score of three being intermediate (neutral) (Likert 1932, Clason and Dormody 1994).

After contacting the heads of NP management boards in 30 NPs to explain the purpose of the survey, the questionnaire survey was sent by an e-mail; the survey itself was conducted between May and December 2016. This survey was also supplemented with phone calls to the respondents to ensure a high rate of response and to gain an insight into the questionnaire. During survey data collection, further data and information was collected through direct contact with NP units (e.g. Unit of Personnel and Administration, Unit of Planning and Finance, Unit of Science and International Cooperation), as well as provincial departments (e.g. Department of Agriculture and Rural Development) to collect data and information in order to support questions from questionnaire surveys. The final response rate to the survey questionnaire was 30/30.

Moreover, 21 interviews were conducted with randomly chosen members of NP management boards to validate questions of the survey and to gather more detailed information on conservation activities and management of NPs (see Appendix 2). Most of interviews were conducted via phone calls, while others were conducted face-to-face.

In this paper, all statistical analyses were performed using STATISTICA 12. Quantitative data were analysed using descriptive statistics. The independent samples $t$-test and Mann-Whitney $U$ test were employed to compare differences between the two groups (McCrum-Gardner 2008). These tests were applicable to the data as they allowed for comparison between two independent groups with different samples sizes. The Mann-Whitney $U$ test was carried out for attitude scores, while the independent samples $t$-test was used for an interval-scale variable. In addition, results were considered significant at $p$-value $\leq 0.05$.

\section{Results}

\section{National parks' profile}

The general characteristics of the 30 surveyed NPs are presented in Table 1 . The average size of a NP was 37,073 ha. Phong Nha - Ke Bang NP was the largest park with 123,326 ha (ca. 11\% of the total area of 1,111,113 ha) and Xuan Thuy NP was the 
Table I. Characteristics of national parks.

\begin{tabular}{l|c|c|c|c}
\hline \multicolumn{1}{c|}{ National parks } & Year of establishment & Area (ha) & Governance & Other designation \\
\hline Ba Be & 1992 & 10,048 & PPC & RS, AHP \\
\hline Ba Vi & 1991 & 10,815 & VNFOREST & - \\
\hline Bach Ma & 1991 & 37,487 & VNFOREST & - \\
\hline Bai Tu Long & 2001 & 15,783 & PPC & MPA \\
\hline Ben En & 1992 & 14,735 & PPC & - \\
\hline Bidoup-Nui Ba & 2004 & 70,038 & PPC & UBR \\
\hline Bu Gia Map & 2002 & 25,779 & PPC & - \\
\hline Cat Ba & 1986 & 17,363 & PPC & UBR, MPA \\
\hline Cat Tien & 1992 & 72,634 & VNFOREST & UBR, RS \\
\hline Chu Mom Ray & 2002 & 56,621 & PPC & AHP \\
\hline Chu Yang Sin & 2002 & 58,971 & PPC & - \\
\hline Con Dao & 1993 & 20,000 & PPC & RS, MPA \\
\hline Cuc Phuong & 1962 & 22,200 & VNFOREST & - \\
\hline Hoang Lien & 2002 & 28,059 & PPC & AHP \\
\hline Kon Ka Kinh & 2002 & 42,143 & PPC & AHP \\
\hline Lo Go - Xa Mat & 2002 & 19,156 & PPC & - \\
\hline Mui Ca Mau & 2003 & 41,862 & PPC & UBR, RS \\
\hline Nui Chua & 2003 & 29,865 & PPC & MPA \\
\hline Phong Nha - Ke Bang & 2001 & 123,326 & PPC & UWHS \\
\hline Phu Quoc & 2001 & 29,421 & PPC & UBR, MPA \\
\hline Phuoc Binh & 2006 & 19,814 & PPC & - \\
\hline Pu Mat & 1997 & 91,113 & PPC & UBR \\
\hline Tam Dao & 1996 & 34,995 & VNFOREST & - \\
\hline Tram Chim & 1998 & 7,588 & PPC & RS \\
\hline U Minh Ha & 2006 & 8,528 & PPC & UBR \\
\hline U Minh Thuong & 2002 & 8,038 & PPC & UBR, RS, AHP \\
\hline Vu Quang & 2002 & 57,038 & PPC & UBR \\
\hline Xuan Son & 2002 & 15,048 & PPC & - \\
\hline Xuan Thuy & 2003 & 7,100 & PPC & RS \\
\hline Yok Don & 1992 & 115,545 & VNFOREST & - \\
\hline Total & & $1,111,113$ & & \\
\hline List of aben & & & - \\
\hline
\end{tabular}

List of abbreviations

PPC: Provincial People's Committee; VNFOREST: Vietnam Administration of Forestry, Ministry of Agriculture and Rural Development; UWHS: United Nations Educational, Scientific and Cultural Organisation World Heritage Site; UBR: United Nations Educational, Scientific and Cultural Organisation Biosphere Reserve; RS: Ramsar Site; AHP: Association for Southeast Asian Nations Heritage Park; MPA: Marine Protected Area.

smallest area (7,100 ha, ca. $1 \%$ of the total area). Six NPs were found to be the responsibility of MARD, which has been decentralised from direct management by the Vietnam Administration of Forestry (VNFOREST). Twenty-four NPs were under the responsibility of provincial authorities. In addition, many NPs or NP areas were 
specified under international and regional agreements, including the international designations (Ramsar Site, United Nations Educational, Scientific and Cultural Organisation [UNESCO] World Natural Heritage Site and UNESCO Biosphere Reserve), as well as regional designations including the Association for Southeast Asia Nations (ASEAN) Heritage Parks (Table 1). Some NPs were also listed in the system of Marine Protected Areas.

\section{The national park management plan}

Of the 30 investigated NPs, the results showed that most of NPs (87\%) had updated their management plans. In particular, $77 \%$ had management plans which had been updated by other management tools. Only four NPs (13\%) indicated that their management plans had not been updated.

The other management tools (e.g. plans, actions) used management plans coordinated and integrated within 23 NPs: two VNFOREST's NPs and 21 provincial NPs (Table 2). More than $50 \%$ of the updated management plans had integrated tools for the community-based forest management and regulations for scientific research activities $(91 \%)$, planning and management of sustainable tourism and ecotourism (83\%) and forest monitoring programmes (74\%).

In the current context of socio-economic development, $90 \%$ of the 30 NPs indicated that their management plans offered sufficient protection for their development plan(s) for local communities and region(s). Only 10\% identified that their management plans were not sufficient for protection because of confusing, conflicting and overlapping institutional and legal frameworks; in addition, a lack of coordination amongst agencies and communities that had a bearing on 7\% of NPs; and the nonexistence of mechanisms or strategies to engage communities in the management of protected areas was identified in 3\% of NPs.

Table 2. The national park management plan updated by other management tools.

\begin{tabular}{l|c|c|c|c|c|c}
\hline \multirow{2}{*}{\multicolumn{1}{c|}{ Management tools }} & \multicolumn{2}{c|}{$\begin{array}{c}\text { All NPs } \\
(\boldsymbol{n}=\mathbf{2 3})\end{array}$} & \multicolumn{2}{c|}{$\begin{array}{c}\text { VNFOREST's NPs } \\
(\boldsymbol{n}=\mathbf{2})\end{array}$} & \multicolumn{2}{c}{$\begin{array}{c}\text { Provincial NPs } \\
(\boldsymbol{n}=\mathbf{2 1})\end{array}$} \\
\cline { 2 - 8 } & $\mathbf{n}$ & $\mathbf{\%}$ & $\mathbf{n}$ & $\mathbf{\%}$ & $\mathbf{n}$ & $\mathbf{\%}$ \\
\hline Multiple-use forest management plan & 9 & 39.13 & 0 & 0 & 9 & 42.86 \\
\hline Forest monitoring programme & 17 & 73.91 & 2 & 100.00 & 15 & 71.43 \\
\hline Regulations for scientific research activities & 21 & 91.30 & 2 & 100.00 & 19 & 90.48 \\
\hline Sustainable tourism development plan & 19 & 82.61 & 2 & 100.00 & 17 & 80.95 \\
\hline Environmental impact assessment & 7 & 30.43 & 0 & 0 & 7 & 33.33 \\
\hline Community-based forest management & 21 & 91.30 & 2 & 100.00 & 19 & 90.48 \\
\hline Forest valuation & 5 & 21.74 & 0 & 0 & 5 & 23.81 \\
\hline
\end{tabular}

List of abbreviations

NPs: National parks; VNFOREST's NPs: Vietnam Administration of Forestry's national parks; n: Number of cases. 


\section{Financial sources in national parks}

The financial sources of the total funding for conservation and management of NPs in 2016 are presented in Table 3. The results indicated that sources of the funding were mainly derived from the state budget, i.e. a mean of $51 \%$ and $76 \%$ came from the central budget and provincial budget respectively. Support from organisations, funds from conservation programmes, revenues from forest environmental services and tourism activities contributed to the total funding for parks. In particular, in $87 \%$ of NPs, a mean of $9 \%$ of their total funding was obtained from tourism activities. The results revealed significant differences between VNFOREST's NPs and provincial NPs with respect to the central and provincial budgets and revenues from forest environmental services (Table 3).

Moreover, $50 \%$ of NPs used $40-60 \%$ of funding for their conservation activities (Table 4). The results demonstrated that $66.67 \%$ of VNFOREST's NPs spent $60-80 \%$ of their funds in conservation activities. Meanwhile, in 46\% of provincial NPs, $40-60 \%$ of funds were invested in conservation activities.

Table 3. Percentages of financial sources of the total funding for national parks.

\begin{tabular}{|c|c|c|c|c|c|c|c|c|c|c|}
\hline \multirow{2}{*}{ Financial sources } & \multicolumn{3}{|c|}{ All NPs } & \multicolumn{3}{|c|}{ VNFOREST's NPs } & \multicolumn{3}{|c|}{ Provincial NPs } & \multirow{2}{*}{$p$-value } \\
\hline & $n$ & Mean & SD & $n$ & Mean & SD & $n$ & Mean & SD & \\
\hline The central budget & 15 & 50.95 & 30.88 & 6 & 75.97 & 33.97 & 9 & 34.27 & 12.83 & $0.005^{*}$ \\
\hline The pro & 25 & 76.24 & 2332 & 1 & & 000 & 24 & & 17.55 & \\
\hline & 3 & 2.10 & 2.54 & 1 & 0.30 & 0.00 & 2 & 3.00 & 2.83 & 0.579 \\
\hline internation & 3 & 2.43 & 2.38 & 1 & 0.30 & 0.00 & 2 & 3.50 & 2.12 & .434 \\
\hline nnservation & 5 & 5.04 & 4.78 & 0 & NA & NA & 5 & .04 & 4.78 & NA \\
\hline Revenues from forest & 7 & 9.40 & 8.12 & 2 & 20.00 & 0.00 & 5 & 5.16 & 4.51 & $0.007^{*}$ \\
\hline $\begin{array}{l}\text { Revenues from tourism } \\
\text { activities }\end{array}$ & 26 & 8.66 & 13.99 & 6 & 17.17 & 26.05 & 20 & 6.11 & 7.01 & 0.090 \\
\hline
\end{tabular}

List of abbreviations

${ }^{\dagger} p$-values were calculated using the independent samples $t$-test between VNFOREST's NPs and provincial NPs; "Significant at $p$-value < 0.05; NPs: National parks; VNFOREST's NPs: Vietnam Administration of Forestry's national parks; n: Number of cases; SD: Standard deviation; NA: Not available.

Table 4. Percentages of national parks having investment levels of the total funding for conservation activities.

\begin{tabular}{l|c|c|c}
\hline & $\begin{array}{c}\text { All NPs } \\
(\boldsymbol{n}=\mathbf{3 0})\end{array}$ & $\begin{array}{c}\text { VNFOREST's NPs } \\
(\boldsymbol{n}=\mathbf{6})\end{array}$ & $\begin{array}{c}\text { Provincial NPs } \\
(\boldsymbol{n}=\mathbf{2 4})\end{array}$ \\
\hline Less than $20 \%$ & 3.33 & 0 & 4.17 \\
\hline $20-40 \%$ & 13.33 & 0 & 16.67 \\
\hline $40-60 \%$ & 50.00 & 0 & 45.83 \\
\hline $60-80 \%$ & 26.67 & 66.67 & 25.00 \\
\hline $80-100 \%$ & 6.67 & 33.33 & 8.33 \\
\hline Total & 100.00 & 100.00 & 100.00 \\
\hline
\end{tabular}

List of abbreviations

NPs: National parks; VNFOREST's NPs: Vietnam Administration of Forestry's national parks; n: Number of cases. 


\section{National park staff}

The total number of staff within the 30 NPs was 3,127 , of which $80 \%$ were forest rangers who worked in forest protection stations and $20 \%$ in other positions such as administrative and service officers. Each of the 2,501 NP forest rangers administrated an average of 444.26 ha. The mean number of staff per park was 104 persons $(S D=74.87)$, while 83 persons were forest rangers $(S D=68.65)$ for each of the 30 NPs. A significant difference in staff numbers was detected between the two groups of NPs (Table 5).

Concerning the educational level of staff, $85 \%$ working in 30 NPs had an academic education with graduates from colleges and higher education. On average, $88 \mathrm{NP}$ staff had an academic education (in $30 \mathrm{NPs}$ ) while 37 had a non-academic education (in $13 \mathrm{NPs}$ ). In addition to the results, a significant difference was found between VNFOREST's NPs and provincial NPs with respect to the staff's academic qualifications (Table 6).

For academic education, Table 7 shows the education background of staff in 30 NPs. NP staff mainly specialised in the fields of forestry, agriculture and fisheries, with approximately $74 \%$ of the total number of staff.

On average, 98 members of staff in VNFOREST's NPs had an academic education in the fields of forestry, agriculture and fisheries, but only 57 persons in the provincial NPs did so (Table 8). Significant differences were found between the two groups with respect to the educational background of 'forestry, agriculture, fisheries' and 'biology, ecology, environmental protection' (Table 8).

Table 5. Staff of national parks.

\begin{tabular}{l|c|c|c|c|c}
\hline & \multicolumn{2}{|c|}{$\begin{array}{c}\text { VNFOREST's NPs } \\
(\boldsymbol{n}=\mathbf{6})\end{array}$} & \multicolumn{2}{c|}{$\begin{array}{c}\text { Provincial NPs } \\
(\boldsymbol{n}=\mathbf{2 4})\end{array}$} & $\boldsymbol{p}^{\text {-value }}$ \\
\hline & Mean & SD & Mean & SD & \\
\hline Staff & 170.00 & 126.31 & 87.79 & 46.78 & $0.013^{*}$ \\
\hline Staff as forest rangers & 141.67 & 125.99 & 68.79 & 37.18 & $0.017^{*}$ \\
\hline
\end{tabular}

List of abbreviations

${ }^{\dagger} p$-values were calculated using the independent samples $t$-test between VNFOREST's NPs and provincial NPs; *Significant at $p$-value < 0.05; NPs: National parks; VNFOREST's NPs: Vietnam Administration of Forestry's national parks; n: Number of cases; SD: Standard deviation.

Table 6. National parks staff profile according to the level of education.

\begin{tabular}{l|c|l|l|l|l|l|l}
\hline \multirow{2}{*}{ Level of education } & \multicolumn{3}{|c|}{ VNFOREST's NPs } & \multicolumn{3}{c|}{ Provincial NPs } & \multirow{2}{*}{-value $^{\dagger}$} \\
\cline { 2 - 9 } & $\boldsymbol{n}$ & \multicolumn{1}{|c|}{ Mean } & SD & $\boldsymbol{n}$ & Mean & \multicolumn{1}{c}{ SD } & \\
\hline Non-academic & 4 & 63.75 & 93.96 & 9 & 24.56 & 25.97 & 0.251 \\
\hline Academic & 6 & 127.50 & 52.94 & 24 & 78.58 & 44.23 & $0.027^{*}$ \\
\hline
\end{tabular}

List of abbreviations

${ }^{\dagger} p$-values were calculated using the independent samples $t$-test between VNFOREST's NPs and provincial NPs; "Significant at $p$-value < 0.05; NPs: National parks; VNFOREST's NPs: Vietnam Administration of Forestry's national parks; n: Number of cases; SD: Standard deviation. 
Table 7. National parks' staff by educational background.

\begin{tabular}{l|c|c|c}
\hline \multirow{2}{*}{ Educational background } & \multirow{2}{*}{\begin{tabular}{c} 
Staff \\
\cline { 3 - 4 }
\end{tabular}} & $\mathbf{( \% )}$ & \multicolumn{2}{c}{ Staff as } \\
\cline { 3 - 4 } & 74.09 & Forest rangers (\%) & Others (\%) \\
\hline Forestry, agriculture, fisheries & 13.24 & 83.54 & 36.87 \\
\hline Economics, business management, law & 5.43 & 4.45 & 30.17 \\
\hline Biology, ecology, environmental protection & 2.72 & 1.42 & 9.31 \\
\hline Tourism & 0.34 & 0.33 & 0.82 \\
\hline Geography, geology, geographic information system & 0.08 & 0.05 & 0.19 \\
\hline Archaeology, history, cultural studies & 4.11 & 1.28 & 15.27 \\
\hline Other majors & 100.00 & 100.00 & 100.00 \\
\hline Total & & &
\end{tabular}

Table 8. Groups of national park staff by educational background.

\begin{tabular}{|c|c|c|c|c|c|c|c|}
\hline \multirow{2}{*}{ Educational background } & \multicolumn{3}{|c|}{ VNFOREST's NPs } & \multicolumn{3}{|c|}{ Provincial NPs } & \multirow{2}{*}{$p$-value } \\
\hline & $n$ & Mean & SD & $n$ & Mean & SD & \\
\hline Biology, ecology, environmental protection & 5 & 11.60 & 7.89 & 17 & 5.06 & 5.36 & $0.043^{*}$ \\
\hline Economics, business management, law & 5 & 14.00 & 6.29 & 20 & 14.05 & 15.52 & 0.994 \\
\hline Forestry, agriculture, fisheries & 6 & 97.50 & 38.95 & 24 & 57.46 & 31.22 & $0.012^{*}$ \\
\hline Tourism & 3 & 4.33 & 2.52 & 13 & 4.54 & 5.62 & 0.953 \\
\hline Geography, geology, geographic information system & 1 & 2.00 & 0.00 & 3 & 2.33 & 1.53 & 0.868 \\
\hline Archaeology, history, cultural studies & 0 & NA & NA & 2 & 1.00 & 0.00 & NA \\
\hline Other majors & 2 & 18.50 & 2.12 & 10 & 7.20 & 9.58 & 0.140 \\
\hline
\end{tabular}

List of abbreviations

${ }^{\dagger} p$-values were calculated using the independent samples $t$-test between VNFOREST's NPs and provincial NPs; 'Significant at $p$-value < 0.05; NPs: National parks; VNFOREST's NPs: Vietnam Administration of Forestry's national parks; n: Number of cases; SD: Standard deviation; NA: Not available.

\section{Cooperation in management and conservation of NPs}

It was found that $77 \%$ of $30 \mathrm{NPs}$ have cooperated with scientific institutes, e.g. universities and international organisations, in the management and conservation of protected areas. Biodiversity conservation and forest management were the most common cooperative activities observed in NPs, with $77 \%$ and $57 \%$ of all NPs in them (Table 9). Similarly, $67 \%$ of VNFOREST's NPs and 79\% of provincial NPs reported collaborative activities in biodiversity conservation.

Moreover, $83 \%$ of the 30 NPs indicated that their activities involved volunteers and schools in various nature conservation programmes/projects. These projects mainly concentrated on environmental education and training (70\% of NPs), survey work and short work-experience placements (47\%) and help with practical conservation tasks (43\%). 
Table 9. Percentages of national parks reporting collaborations with different activities.

\begin{tabular}{l|c|c|c|c|c|c}
\hline \multicolumn{1}{c|}{ Management tools } & \multicolumn{2}{|c|}{$\begin{array}{c}\text { All NPs } \\
(\boldsymbol{n = 3 0 )}\end{array}$} & \multicolumn{2}{c|}{$\begin{array}{c}\text { VNFOREST's NPs } \\
(\boldsymbol{n}=\mathbf{6})\end{array}$} & \multicolumn{2}{c}{$\begin{array}{c}\text { Provincial NPs } \\
(\boldsymbol{n}=\mathbf{2 4})\end{array}$} \\
\hline & $n$ & $\%$ & $n$ & $\%$ & $n$ & $\%$ \\
\hline Species monitoring & 13 & 43.33 & 2 & 33.33 & 11 & 45.83 \\
\hline Forestry management & 17 & 56.67 & 2 & 33.33 & 15 & 62.50 \\
\hline Eco-tourism management and development & 10 & 33.33 & 1 & 16.67 & 9 & 37.50 \\
\hline $\begin{array}{l}\text { Socio-economic development in buffer zone } \\
\text { of the national park }\end{array}$ & 12 & 40.00 & 1 & 16.67 & 11 & 45.83 \\
\hline Biodiversity conservation & 23 & 76.67 & 4 & 66.67 & 19 & 79.17 \\
\hline Education and training & 11 & 36.67 & 1 & 16.67 & 10 & 41.67 \\
\hline $\begin{array}{l}\text { Other activities (e.g. conservation of } \\
\text { cultural heritage, historic sites) }\end{array}$ & 8 & 26.67 & 1 & 16.67 & 7 & 29.17 \\
\hline
\end{tabular}

List of abbreviations

NPs: National parks; VNFOREST's NPs: Vietnam Administration of Forestry's national parks; n: Number of cases.

\section{Perspectives on the conservation and management of NPs}

The management boards of the surveyed NPs were requested to use a scale from 1 (strongly disagree) to 5 (strongly agree) to score their perceptions of the major causes of limited management capacity and threats to conservation and management of natural resources.

Table 10 shows the major causes of limited management capacity for NPs: The highest average scores were obtained for 'lack of funding for the national park' (4.13) and 'population and resource use pressure within and around the national park' (4.74). The lowest average scores were found for focusing on hard infrastructure instead of conservation activities (2.53) and construction of infrastructure within the NP (2.63). The average scores for 'limited human and institutional capacity of the national park' and 'land use conflict/land grab' were equal at 3.60. NPs also dealt with 'overlapping and conflicting institutional mandates' (3.27) and 'lack of enforcement authority for national park management boards' (3.07). In these results, no significant differences were found between the VNFOREST's NPs and provincial NPs with respect to causes of limited management capacity for protected areas.

Concerning threats to natural resources in NPs, the highest average scores were found for 'illegal hunting, trapping, poaching, fishing' (4.23), 'illegal trade in wildlife' (3.93) and 'illegal logging, firewood collecting' (3.63), indicating that these were the main threats (Table 11). In particular, the highest average score for VNFOREST's NPs was 4.67 for 'illegal logging, firewood collecting', while the highest average score for provincial NPs was 4.21 for 'illegal hunting, trapping, poaching, fishing'. The only significant difference was detected between VNFOREST's NPs and provincial NPs concerned illegal logging and firewood collecting $(U=23, z=2.51$, $p$-value $=0.009)$. 
Table 10. Major causes of limited management capacity of national parks, rated from 1 (strongly disagree) to 5 (strongly agree), with a score of 3 representing neutral.

\begin{tabular}{l|c|c|c|c|c|c|c}
\hline & \multicolumn{2}{|c|}{$\begin{array}{c}\text { All NPs } \\
(\boldsymbol{n}=\mathbf{3 0})\end{array}$} & \multicolumn{2}{c|}{$\begin{array}{c}\text { VNFOREST's NPs } \\
(\boldsymbol{n}=\mathbf{6})\end{array}$} & \multicolumn{2}{c|}{$\begin{array}{c}\text { Provincial NPs } \\
(\boldsymbol{n}=\mathbf{2 4})\end{array}$} & \multirow{2}{*}{${\text { - } \text {-value }^{\dagger}}^{\dagger}$} \\
\cline { 2 - 9 } & Mean & SD & Mean & SD & Mean & SD & \\
\hline Lack of funding for the national park & 4.13 & 0.86 & 4.00 & 0.89 & 4.17 & 0.87 & NS \\
\hline $\begin{array}{l}\text { Lack of enforcement authority for } \\
\text { national park management boards }\end{array}$ & 3.07 & 1.23 & 3.17 & 1.47 & 3.04 & 1.20 & NS \\
\hline $\begin{array}{l}\text { Overlapping and conflicting } \\
\text { institutional mandates }\end{array}$ & 3.27 & 1.17 & 3.17 & 1.17 & 3.29 & 1.20 & NS \\
\hline $\begin{array}{l}\text { Focus on hard infrastructure instead } \\
\text { of conservation activities }\end{array}$ & 2.53 & 1.07 & 2.17 & 0.98 & 2.63 & 1.10 & NS \\
\hline $\begin{array}{l}\text { Limited human and institutional } \\
\text { capacity of the national park }\end{array}$ & 3.60 & 0.97 & 3.33 & 1.03 & 3.67 & 0.96 & NS \\
\hline $\begin{array}{l}\text { Population and resource use pressure } \\
\text { within and around the national park }\end{array}$ & 4.47 & 0.68 & 4.33 & 0.52 & 4.50 & 0.72 & NS \\
\hline $\begin{array}{l}\text { Construction of infrastructure within } \\
\text { the national park }\end{array}$ & 2.63 & 0.93 & 2.50 & 0.55 & 2.67 & 1.01 & NS \\
\hline Land use conflict/land grab & 3.60 & 1.43 & 3.50 & 1.05 & 3.63 & 1.53 & NS \\
\hline
\end{tabular}

List of abbreviations

${ }^{\dagger} p$-values were calculated using the Mann-Whitney $U$ test between VNFOREST's NPs and provincial NPs; NS: No statistically significant difference; NPs: National parks; VNFOREST's NPs: Vietnam Administration of Forestry's national parks; n: Number of cases; SD: Standard deviation.

Table II. Threats to natural resources in national parks rated from 1 (strongly disagree) to 5 (strongly agree), with a score of 3 representing neutral.

\begin{tabular}{|c|c|c|c|c|c|c|c|}
\hline & \multicolumn{2}{|c|}{$\begin{array}{l}\text { All NPs } \\
(n=30)\end{array}$} & \multicolumn{2}{|c|}{$\begin{array}{c}\text { VNFOREST's NPs } \\
(n=6)\end{array}$} & \multicolumn{2}{|c|}{$\begin{array}{c}\text { Provincial NPs } \\
(n=24)\end{array}$} & \multirow[t]{2}{*}{$p$-value ${ }^{\dagger}$} \\
\hline & Mean & SD & Mean & SD & Mean & SD & \\
\hline $\begin{array}{l}\text { Illegal hunting, trapping, poaching, } \\
\text { fishing }\end{array}$ & 4.23 & 0.94 & 4.33 & 0.52 & 4.21 & 1.02 & NS \\
\hline Illegal trade in wildlife & 3.93 & 1.08 & 4.17 & 0.75 & 3.88 & 1.15 & NS \\
\hline Illegal logging, firewood collecting & 3.63 & 1.13 & 4.67 & 0.52 & 3.38 & 1.10 & $0.009^{*}$ \\
\hline $\begin{array}{l}\text { Non-timber forest product collection } \\
\text { illegally }\end{array}$ & 3.40 & 1.25 & 4.17 & 0.75 & 3.21 & 1.29 & NS \\
\hline Mineral exploitation, quarrying & 2.17 & 1.26 & 2.00 & 1.27 & 2.21 & 1.29 & NS \\
\hline Hydroelectric dam/projects, dams & 2.57 & 1.31 & 2.83 & 1.47 & 2.50 & 1.29 & NS \\
\hline Developing dykes and canals & 2.13 & 0.97 & 2.17 & 0.98 & 2.13 & 0.99 & NS \\
\hline $\begin{array}{l}\text { Existing and planned routes (roads, } \\
\text { motorways, train tracks) crossing } \\
\text { national park or situated in its vicinity }\end{array}$ & 3.07 & 1.29 & 2.33 & 1.51 & 3.25 & 1.19 & NS \\
\hline $\begin{array}{l}\text { Pollution (water, soil, air, noise } \\
\text { pollution) }\end{array}$ & 3.60 & 1.16 & 3.83 & 0.98 & 3.54 & 1.22 & NS \\
\hline
\end{tabular}




\begin{tabular}{l|c|c|c|c|c|c|c}
\hline & \multicolumn{2}{|c|}{$\begin{array}{c}\text { All NPs } \\
(\boldsymbol{n}=\mathbf{3 0})\end{array}$} & \multicolumn{2}{c|}{$\begin{array}{c}\text { VNFOREST's NPs } \\
(\boldsymbol{n}=\mathbf{6})\end{array}$} & $\begin{array}{c}\text { Provincial NPs } \\
(\boldsymbol{n}=\mathbf{2 4})\end{array}$ & \multirow{2}{*}{$\boldsymbol{p}$-value ${ }^{\dagger}$} \\
\cline { 2 - 9 } & Mean & SD & Mean & SD & Mean & SD & \\
\hline Land use change & 3.07 & 1.26 & 2.67 & 1.37 & 3.17 & 1.24 & NS \\
\hline $\begin{array}{l}\text { Tourism development (overlapping } \\
\begin{array}{l}\text { intensive tourism and related pressure } \\
\text { to invest in tourist infrastructure in } \\
\text { the national park and its vicinity) }\end{array}\end{array}$ & 2.77 & 1.07 & 2.83 & 0.75 & 2.75 & 1.15 & NS \\
\hline
\end{tabular}

List of abbreviations

${ }^{\dagger} p$-values were calculated using the Mann-Whitney $U$ test between VNFOREST's NPs and provincial NPs; "Significant at $p$-value < 0.05; NS: No statistically significant difference; NPs: National parks; VNFOREST's NPs: Vietnam Administration of Forestry's national parks; n: Number of cases; SD: Standard deviation.

\section{Discussion}

The results of the study identify interesting aspects regarding the conservation and management of natural resources in 30 NPs in Vietnam. It was found that some NPs were still using outdated management plans. To protect an area over a given period of time, a documented management plan needs to set out the management approach and goals, together with a framework for decision-making (Thomas and Middleton 2003). A comprehensive NP management plan is considered to be vital for the effective management of protected areas and should be accompanied by a number of other plans or related documents and tools, e.g. operational and conservation plans (Thomas and Middleton 2003, Leverington et al. 2008, Worboys and Trzyna 2015, Spoelder et al. 2015). NP managers should accept the need to establish schedules and procedures through periodic review and updating of management plans (Thomas and Middleton 2003); for example, they should revise and update their management plans within a set period (a five-year or 10-year period), during which they could forecast conditions and offer solutions to management challenges into the future. With an updated management plan, NPs could readily adapt to challenges in social and economic development at local and regional levels and protected areas would not be managed as 'islands' in isolation from their surrounding regions (McCuaig 2010).

These findings indicate that updated NP management plans lacked the potential for integrating other tools and plans (e.g. buffer zone development plan). Many NPs lacked any integration of a biodiversity monitoring programme. In this context, confusion might result when determining biodiversity conservation priorities and effective management of natural resources, e.g. the success of activities taken to conserve or recover species and their habitats. The PARC Project (2006) also found that there was no adequate process for management planning according to conservation priorities in Vietnam's protected areas. In the concept of preparing management plans, if the status of biodiversity and other such natural values had been updated, NP planners and managers would perform adaptive management of trends in biodiversity, as well as of impacts on natural resources. Revising and updating the status of management plans 
within a set period (e.g. 10 years) would be an effective and efficient contribution to NP management and help managers of protected areas in creating a sound investment plan for their priority activities. The evaluation and ranking of objectives and priorities in management plans would allow capacities of NPs such as finance to be allocated. According to the present findings, $10 \%$ of NPs indicated that their management plans (i.e. outdated management plans) were not flexible enough to be adapted to current local and regional development plans; for example, $7 \%$ reported a lack of coordination amongst agencies and communities in management plans which influenced the effective management and conservation of natural resources. These findings suggest that the cooperation and support of local people is needed for the successful management of NPs. The preparation and development of management plans should gain the support of key stakeholders, particularly from local communities, who would assist in delivering these plans and contribute to the effective implementation of plans in protected areas (Mishra 1994, Thomas and Middleton 2003, Spoelder et al. 2015),

Regarding financial sources, these results showed that central and provincial budgets were crucial funding sources to cover the costs of NP management and conservation. Central and provincial budgets are derived from the state budget of the Government of Vietnam. This result was consistent with Emerton et al. (2006), who stated that NPs in most countries were financed predominantly from state budgets. This was also the case with developed countries, e.g. about 69\% of funding for Polish NPs in 2011 came from the public budget (Ministry of the Environment of Poland 2011) and an average of $88 \%$ of the Parks Service funding in the United States came from annual budget appropriations (Longley 2016). Emerton et al. (2006) indicated that state budget allocations for protected areas in Vietnam ranged from US $\$ 3.0$ to 3.5 million per year, an average of $0.1 \%$ of Gross Domestic Product and $0.5 \%$ of total public budget allocations. Although financial sourcing from state budgets was long-term and covered basic running costs of protected areas, including NPs, it was often insufficient to finance the entire scope of activities within protected areas (Athanas et al. 2001).

In addition to the state budget, significant differences were found between the two groups of NPs with respect to central and provincial budgets (Table 3). The VNFOREST's NPs were mainly funded from the central budget, while the provincial budget supported provincial NPs. Provincial NPs received the central budget which was invested in infrastructure development projects, for example, offices and lodging facilities for staff or roads. In Vietnam, through the annual budgeting process, the Ministry of Planning and Investment was responsible for setting funding levels and negotiating budget allocations with sectoral ministries and provinces, including the state budget for NPs (GoV 2008c). As a result, the budgets for NPs were allocated annually and depended on the balance between the state and provincial budgets. Expenditure of the state budget for the VNFOREST's NPs was higher than for the provincial NPs as the state budget was estimated based on the number of staff in each NP (VNFOREST 2014). Provincial NPs generally had less access to funds than those managed by MARD (Emerton et al. 2012).

Other important sources of funding for the NPs in Vietnam included support from domestic and international organisations, such as the German Society for Inter- 
national Cooperation and Japan International Cooperation Agency, as well as funds from conservation programmes: for example, the Vietnam Conservation Fund (Emerton et al. 2012, USAID 2013, VNFOREST 2014). Despite being dependent upon short-term funding and projects, these sources contributed to significant amounts of financing for conservation activities, enhancing the management capacity of NPs and socio-economic development in buffer zones (VNFOREST 2014). From these survey results, some NPs had valid support from organisations (10\%) and funds from conservation programmes $(17 \%)$. These results suggest that NP managers should enhance their ability to attract additional funding from agencies and organisations, for example, by creating and building a team with successful funding (Athanas et al. 2001).

The Vietnamese NPs generated their own funds as revenues from forest environmental services and tourism activities. Drawing on the concept of payment for environmental services (PFES), NPs reported incomes from PFES payments from such sources as hydropower and water companies (Pham et al. 2013, Trædal et al. 2015). The development of 'innovative' financing mechanisms, such as PFES, provided increasing funding for NPs in biodiversity conservation and, at the same time, generated financial and economic incentives for local communities in buffer zones in protecting forests (Emerton et al. 2012, Pham et al. 2013, USAID 2013).

Tourism, or rather nature-based tourism, could be a particularly effective tool in the conservation and management of protected areas and can bring direct and indirect benefits; for example, tourism not only generated funds for conservation but also shaped people's attitudes to the environment and natural resources (Emerton et al. 2006, Eagles and Hillel 2008, Balmford et al. 2009). Eagle and Hillel (2008) indicated that, despite a fall in the proportion of state budgets allocated to protected areas, revenues from tourism were increasing and it was clear that NPs in Vietnam could increase their share of funding from tourism-based activities. The present study reveals a significant difference between the two groups with respect to revenues from forest environmental services: i.e. VNFOREST's NPs reported a significantly higher revenue than provincial NPs due to the implementation of PFES in NPs; however, no statistically significant difference was found between the two groups with respect to revenues from tourism activities. The results of the interviews indicated that NP managers encouraged benefits from nature-based tourism development, particularly in the economic sphere. However, nature-based tourism was a competitive market and NPs had to offer high quality as well as unique environmental characteristics to succeed in tourism development. The results of the present study suggest that both tourism and forest environmental services were crucial in increasing the funds of NPs and in creating sustainable financial sources of funding for Vietnamese NPs.

The degree of investment for conservation activities in protected areas was reflected in the percentages of financial allocations. The results showed that NPs were interested in biodiversity conservation and had prioritised investment for conservation, e.g. $40-60 \%$ of funds were invested in conservation activities in $50 \%$ of NPs and $46 \%$ of provincial NPs, (Table 4). In particular, all VNFOREST's NPs allocated more than $60 \%$ of their funds for conservation activities (e.g. conservation of species and habitat). 
However, through interviews, it was found that the financial investment for conservation activities mainly depended on funding being provided to NPs and allocations of financial sources for NPs, indicating that financial allocations for biodiversity conservation in NPs could be changed over the years.

The number and quality of national park staff reflected the capacity of managerial organisation and were central to the success of the management of protected areas. Comparing data from VNFOREST (2014), the total staff size of 30 NPs grew from 2,783 in 2014 to 3,127 in 2016, an increase of $12 \%$. However, it was found that the mean value of land being managed by each forest ranger was 444.26 ha, which was lower than Government guidelines: According to the Government of Vietnam, each forest ranger had to manage 500 ha of protected area (GoV 2010) and so the current number of rangers was deficient and NP managers were obliged to increase their number. VNFOREST's NPs were found to have significantly higher numbers of staff and forest rangers, significantly more highly qualified staff than the provincial NPs. Although $85 \%$ of NP staff reported completing an academic degree, the educational background of these staff focused on the field of forestry, agriculture and fisheries (74\%), of which $84 \%$ of these fields were forest rangers. These findings demonstrated a restricted field of expertise across the group of NPs, e.g. 5\% of staff reported academic education in the fields of Biology, Ecology and Environmental protection. The VNFOREST's NPs had significant higher numbers of staff than provincial NPs with qualifications in 'Biology, Ecology, Environmental protection' and 'Forestry, Agriculture, Fisheries'. In total, these results reveal that VNFOREST's NPs have a higher quantity and quality of staff than provincial NPs.

These results found biodiversity conservation in areas associated with nature protection and NP management, such as the conservation of endangered, rare species and their habitats, to be a priority area for cooperative action with scientific institutes. This demonstrates that the priority of NPs is biodiversity conservation. In addition to cooperative activities, there were organisations (specifically international and non-governmental organisations) whose interventions which aimed to promote biodiversity conservation and the management of natural resources in Vietnam (see USAID 2013). Various cooperative activities contributed to enhancing the capacity of NP staff both directly and indirectly and were able to raise financial resources for NPs. Most of the NPs (83\%) also involved volunteers and schools in their nature conservation projects, particularly in environmental education and training activities. This finding was consistent with previous studies that volunteers played an increasing role in nature conservation (Wearing 2001, Halpenny and Caissie 2003).

The limited management capacity observed in NPs was attributed to the need for NP managers to deal with the human population growth and the pressure placed on protected areas by resource use (an average score of 4.47). In Vietnam, ca. 31\% of population live in or near forests and depended for some part of their subsistence on forest resources (GoV 2005). More than $80 \%$ of protected areas were inhabited and the populations in their buffer zones were increasing (PARC Project 2006). The rapid population growth near protected areas was one of the main causes for the loss 
of biodiversity identified in the country (GoV et al. 2010). Through interviews, it was found that the livelihoods of local communities living within and around most of the NPs heavily depended on agricultural activities (e.g. cultivation and livestock rearing) and the extraction of forest products (e.g. collection of non-timber forest products). The human population growth and livelihoods of local communities were also major threats to natural resources and NP management (Nguyen Huynh Thuat and Yen Hoang Mai 2013, Le Quy Minh 2013, Duong Van Hung 2013).

Strong dependence on the state budget resulted in a lack of sufficient funds for protected areas and limited management capacity for NPs. Even in some NPs, funds only covered full operation and maintenance costs (ICEM 2003). The funds for protected areas tended to be concentrated more on infrastructure development and, to lesser degree, on operations and maintenance, than on investing in conservation activities (ICEM 2003, Ha Thi Mung and Tuyet Hoa Nie Kdam 2008, VNFOREST 2014). Facing situations with insufficient funds, it was difficult to implement long-term commitments in conservation and management of protected areas, as well as maintaining the existing condition of NPs.

Limited human and institutional capacity of NPs and the incidence of land grab, both with a mean score of 3.60, were barriers reported by NP managers. This finding was consistent with previous reports that NPs had to contend with human resources problems, such as a lack of quantity and limited quality of staff working for biodiversity conservation, as well as addressing forest environmental services and nature-based tourism, international cooperative activities and publicity and education for communities (MONRE 2014, VNFOREST 2014). This was reflected in the ratio between the educational fields of the employees being biased towards the fields of Forestry, Agriculture and Fisheries (Table 7). Land use conflicts and land grabbing occurred on NPs because of the presence of overlapping boundary phenomena (VNFOREST 2014), forest conservation policy and disjunction between the objectives of conservation and the livelihoods of communities (To Xuan Phuc 2009, Nguyen Huynh Thuat and Yen Hoang Mai 2013).

In the context of management and organisation structure, NP managers indicated some overlapping and conflicting institutional mandates (with an score of 3.27). As discussed by Nguyen KimDung et al. (2012) and VNFOREST (2014), no clear division was found between functions and tasks for managing NPs, especially provincial NPs, with the areas of responsibility being overlapping, fragmented and unclear. For example, although the provincial Department of Agriculture and Rural Development received technical instructions from their national line ministries and manages the expertise and professional work of the NPs, they were however accountable to the Provincial People's Committee. Both MARD and MONRE had a mandate to manage NPs but with different institutional objectives such as biodiversity conservation (GIZ and MARD 2012, USAID 2013). The responsibility for NPs with other designations, such as marine protected areas, Ramsar sites, ASEAN Heritage Parks and UNESCO Biosphere Reserves, was divided between MONRE, responsible for conservation and protection of wetlands, AHPs, UBRs (GoV 2003, MONRE 2004, GoV 2017) and 
MARD, responsible for developing the system of MPAs (GoV 2008); in addition, MARD maintained control for protection of these protected areas. The Ministry of Culture, Sport and Tourism together with MARD had the responsibility for managing cultural, historical and environmental sites (e.g. NPs as UNESCO World Heritage Sites) and developing the country's tourism strategy and promoting tourism in the NPs (GoV 2013). The lack of enforcement authority for NP management boards influenced the capacity of NP managers (a mean score of 3.07). This finding was consistent with that of the PARC Project (2006), which noted that management boards had not been given the authority and support required to effectively carry out their duties. The authority and responsibility of management boards were unclear and there was no guidance on board structure.

The focus on hard infrastructure and the construction of infrastructure within protected areas resulted in limited management capacity for NPs. Except for office buildings, 11 out of $30 \mathrm{NPs}$ had a lack of necessary infrastructure (e.g. facilities for scientific research, tourism service and environmental education centre) (VNFOREST 2014). Infrastructure in NPs should be upgraded to support managerial activities by, for example, the provision of office buildings. The PARC Project (2006) found that more than $60 \%$ of the state budget for protected areas went to infrastructure development, particularly in chronic underfunding of protected areas under the jurisdiction of Provincial People's Committees (USAID 2013). Infrastructure construction within NPs (e.g. roads, dams and dykes) led to an adverse effect on ecosystem functions, increasing human access and habitat fragmentation (USAID 2013, MONRE 2014).

Regarding threats to NP natural resources, the highest average score (4.23) was awarded to illegal hunting, trapping, poaching and fishing. This was consistent with Nguyen (2009), who noted that illegal hunting appeared to be the most serious threat to wild cattle in Cat Tien and Yok Don NPs. With demand for wildlife and wildlife products and pet trade expected to increase, pressures on illegal hunting, trapping, poaching and fishing were increasing and were threatening the existence of species and conservation of biodiversity in NPs (MARD 2003, Nuwer and Bell 2013). Species populations, particularly those of endangered species, had been continuously declining as a consequence of illegal hunting (Nguyen Manh Ha et al. 2007) and this decline in some cases was responsible for the extinction of species (Bennett et al. 2002), such as in the case of Javan rhinos in Vietnam (Baraniuk 2016). With a mean score of 3.93, the illegal trade in wildlife was the second most serious threat to many species in NPs and undermined efforts to protect natural resources. Nguyen Manh $\mathrm{Ha}$ et al. (2007) indicated that the number of illegal trade and violations of wildlife trade had been recorded as very high in provinces and regions of Vietnam. The illegal wildlife trade has continued unabated. Vietnam was a thriving wildlife market and an important crossroads for the illegal wildlife trade from South-East Asia to neighbouring countries (Nguyen Van Song 2008). Additionally, major sources of illegal wildlife trade are protected areas or NPs.

Illegal logging and firewood collecting were the third serious threat in NPs, even the most serious threat in VNFOREST's NPs (an average score of 4.46). The limited 
amount of forest cover and the high demands for timber and wood products played a large role in encouraging illegal logging in Vietnam (McElwee 2004). In particular, Vietnam was one of five principal suppliers of illegal tropical hardwood in the AsiaPacific region to China's wood imports (Jiao 2016). Illegal logging had a negative impact on NPs, affecting the native environment and the species within them, as well as resulting in economic and social consequences. The practice resulted in biodiversity depletion, soil erosion and enhanced carbon dioxide emissions (Humphreys 2016).

Moreover, the illegal harvesting of non-timber forest products (NTFPs) (e.g. medicinal plants, honey bees and bamboo shoots) threatened the natural resources of the NPs. As commercial demand increased, harvesting rates intensified and over-exploitation of NTFPs occurs, wrecking the ecology, biodiversity and habitats of species. For example, honey was collected for both local utilisation and commercial sale and this practice had been the cause of forest fires which threatened the conservation of species in Pu Mat NP (Luu Tuong Bach and Rawson 2011).

Environmental pollution had an influence on an ecosystem, biodiversity losses and degradation of NPs. For example, water pollution could lead to the destruction of natural habitats (MONRE 2014). Environmental pollution occurred due to anthropological activities in NPs' buffer zones and overheated economic development (Haneji et al. 2014, Khai and Yabe 2014). The rapid development of industries and an increase in shrimp farming resulted in biodiversity losses in wetlands such as Tram Chim NP (Khai and Yabe 2014).

Land use change, existing and planned routes, having the same average scores of 3.07, threatened biodiversity and natural resource management. The conversion of natural forests and wetlands to other forms of land use (e.g. agriculture and aquaculture, industrial plantations, construction land) has led to fragmentation of ecosystems and natural habitats and contributed to the degradation and loss of biodiversity (MONRE 2014, Khai and Yabe 2014). Existing and planned routes increased access to protected areas and added to the fragmentation of forests, wetlands and other isolated natural habitats (USAID 2013). For example, the construction of Cam Lo - Tuy Loan highway, a section of the Ho Chi Minh Trail, crossed the core zone of Bach Ma NP (with a total of $9 \mathrm{~km}$ and 49 ha of forests) (Vietnam News 2016), influenced biodiversity losses and habitat fragmentation. In many cases, routes are implicated in the illegal trade of wildlife and logging (McElwee 2004, Nguyen Manh Ha et al. 2007).

Developing dykes, canals and hydroelectric/dam projects had an impact on the loss of biodiversity resources in NPs, such as habitat loss and fragmentation (CarewReid et al. 2010, USAID 2013). Illegal mineral exploitation appeared to be a threat to the environment and conservation of wildlife in some areas of NPs such as illegal gold mining activities in the Pu Mat and Chu Mon Ray NPs (Luu Tuong Bach and Rawson 2011, Dinh Chieu 2017). Mineral exploitation in NPs' buffer zones affected the ecosystem and habitat of species. For example, illegal sand mining, upstream of Dong Nai River, the Cat Tien NP's buffer zone, has affected the natural flow of water into the river, causing landslides and soil creep and has had an adverse influence on animals in the park with noise and air pollution (Dinh Du et al. 2017). 
Despite scoring 2.77, tourism development could be a potentially important threat to natural resources in NPs. Nature-based tourism might have negative impacts on protected areas, affecting both the environment and species within them (Steven et al. 2011). Increasing numbers of tourists could threaten the fragile ecosystems of NPs with, for example, their accompanying increased accumulation of waste (Nguyen Huynh Thuat and Yen Hoang Mai 2013). The development of tourism infrastructure influenced environmental degradation and habitat fragmentation (Nguyen Huynh Thuat and Yen Hoang Mai 2013, Duong Van Hung 2013). In addition, the lack of a tourism development plan could threaten the sustainability of NPs (Le Quy Minh 2013). On the other hand, tourism might also have a considerable potential for raising funds for NPs, therefore contributing to biodiversity conservation and management of natural resources (Athanas et al. 2001, Emerton et al. 2006, Eagles and Hillel 2008, Balmford et al. 2009; Schägner et al. 2016).

\section{Conclusion}

Vietnam's NPs function within the system of special-use forests, which is considered the backbone of the national strategy for nature protection in the country (PARC Project 2006). Many NPs or areas within NPs are recognised internationally: one is a UNESCO World Heritage site, nine are included in the UNESCO World Network of Biosphere Reserves and areas within seven NPs are protected under the Ramsar Convention. Five NPs are recognised regionally as the ASEAN Heritage Parks. Five NPs are in the national system of Marine Protected Areas.

These findings identify some challenges faced by the conservation and management of natural resources in 30 NPs, including six VNFOREST's NPs and 24 provincial NPs. The results showed that about $87 \%$ of management plans of NPs had been updated. Financial sources for NPs mainly came from the state budget and most of NPs spent about half of their funds on conservation activities. Despite principally depending on the state budget, NPs had opportunities for increasing funding for their conservation and management; for example, NP managers could increase their own funds from nature-based tourism development. Also, having varied sources of funding could help NP managers in their management decisions and ensure the effective implementation of long-term commitments in conservation activities and natural resource management.

Most NPs' staff were found to have academic degrees. However, this educational background was found to offer little variety across disciplines. Hence, NP managers should continuously concentrate on the development of human resources, including the quantity and quality of staff for undertaking the assigned tasks effectively. In Vietnam's NPs, biodiversity conservation was a priority cooperative action with scientific institutes.

The present findings indicate the most common causes of limited management capacity of NPs to be (1) the pressure placed by the human population growth and 
resource use pressure within and around protected areas, (2) the lack of funding, (3) limited human and institutional capacity and (4) land use conflict/land grab. These results also indicated that (1) illegal hunting, trapping, poaching and fishing; (2) illegal wildlife trade; and (3) illegal logging and firewood collecting were regarded as the most serious threats to natural resources in NPs. Significant differences were also found between the VNFOREST's NPs and provincial NPs with respect to financial sources of funding (the central and provincial budgets, revenues from forest environmental services) and staff. Except for the threat of illegal logging and firewood collecting, no significant differences were detected between the two groups with respect to causes of limited management capacity and threats to natural resources.

Further research can build upon the findings of this study to seek solutions and strategies for effective management of NPs. The findings of this study partly may provide useful information for protected area planners, managers and policy makers, as well as researchers and allow them to more effectively manage and conserve the biodiversity of Vietnam's NPs. It is hoped that this study will support the effective management of NPs and the sustainable management of natural resources and biodiversity protection in Vietnam.

\section{Acknowledgments}

The authors would like to thank the managers of NPs who spent their time responding to the survey and interviews. Acknowledgement of financial support is attributed to the Polish Ministry of National Education and the Vietnamese Ministry of Education and Training for awarding PhD scholarships. We would also like to thank the reviewers who helped us to greatly improve the manuscript.

\section{References}

Athanas A, Vorhies F, Ghersi F, Shadie P, Shultis J (2001) Guidelines for Financing Protected Areas in East Asia. IUCN, Gland and Cambridge, 96 pp.

Balmford A, Beresford J, Green J, Naidoo R, Walpole M, Manica A (2009) A global perspective on trends in nature-based tourism. PLoS Biology 7(6): e1000144. https://doi.org/10.1371/ journal.pbio.1000144.

Balmford A, Green JMH, Anderson M, Beresford J, Huang C, Naidoo R, Walpole M, Manica A (2015) Walk on the wild side: Estimating the global magnitude of visits to protected areas. PLoS Biol 13(2): e1002074. https://doi.org/10.1371/journal.pbio.1002074

Baraniuk C (2016) We know exactly how the Vietnamese Javan rhino went extinct. http://www.bbc. com/earth/story/20160920-we-know-exactly-how-the-vietnamese-javan-rhino-went-extinct

Bennett EL, Milner-Gulland EJ, Bakarr M, Eves HE, Robinson JG, Wilkie DS (2002) Hunting the world's wildlife to extinction. Oryx 36(04): 328-329. https://doi.org/10.1017/ S0030605302000637 
Butler RA (2016) The top 10 most biodiverse countries: What are the world's most biodiverse countries? https://news.mongabay.com/2016/05/top-10-biodiverse-countries/

Carew-Reid J, Josh K, Alison C (2010) Biodiversity and development of the hydropower sector: Lessons from the Vietnamese experience - Volume I: Review of the effects of hydropower development on biodiversity in Vietnam. International Centre for Environmental Management (ICEM), Prepared for the Critical Ecosystem Partnership Fund, Hanoi.

Chape S, Blyth S, Fish L, Fox P, Spalding M [compilers] (2003) 2003 United Nations List of Protected Areas. IUCN, Gland and Cambridge, and UNEP-WCMC, Cambridge, 44 pp. Clason DL, Dormody TJ (1994) Analyzing data measured by individual Likert-type items. Journal of Agricultural Education 35(4): 31-35. https://doi.org/10.5032/jae.1994.04031

Dinh Chieu (2017) Kon Tum: Phát hiện bãi vàng trái phép tại vườn quốc gia Chư Mom Ray [Kon Tum: Illegal gold mining in Chu Mon Ray national park]. http://vtv.vn/phap-luat/kontum-phat-hien-bai-vang-trai-phep-tai-vuon-quoc-gia-chu-mom-ray-2017030619041831. htm [In Vietnamese]

Dinh Du, Nguyen Du, Thao Le (2017) Nhờ 'lá bùa' cấp phép, đơn vị khai thác cát 'băm nát' sông Đồng Nai [Because of getting 'talisman' licences, sand mining companies 'damaged' the Dong Nai River]. http://www.tienphong.vn/xa-hoi/nho-la-bua-cap-phep-don-vi-khaithac-cat-bam-nat-song-dong-nai-1134851.tpo [In Vietnamese]

Dudley N (Ed.) (2008) Guidelines for Applying Protected Area Management Categories. IUCN, Gland, 1-86. https://doi.org/10.2305/IUCN.CH.2008.PAPS.2.en

Duong Van Hung (2013) Tam Dao national park. In: Sunderland TCH, Sayer J, Hoang MH (Eds) Evidence-based conservation: lessons from the lower Mekong. CIFOR, Bogor, Indonesia, 50-60.

Eagles P, Hillel O (2008) Improving protected area finance through tourism. In: Secretariat of the Convention on Biological Diversity, Protected areas in today's world: Their values and benefits for the welfare of the planet. Technical Series No. 36, Montreal, 77-86.

Emerton L, Bishop J, Thomas L (2006) Sustainable financing of protected areas: A global review of challenges and options. IUCN, Gland and Cambridge, 97 pp. https://doi.org/10.2305/ IUCN.CH.2005.PAG.13.en

Emerton L, Pham Xuan Phuong, Ha Thi Mung (2012) Protected areas financing mechanisms in Vietnam: Lessons learned and future directions. GIZ/MARD Project "Preservation of Biodiversity in Forest Ecosystems in Vietnam”, Hanoi, 1-54.

GIZ - German Society for International Cooperation, MARD - Ministry of Agriculture and Rural Development (2012) Policy brief: Strengthening biodiversity conservation in Viet Nam's Protected Area System: key issues to address in the governing, legal, institutional and administrative framework. https:/www.deutsche-digitale-bibliothek.de/binary/ HQOLEQRRUN4XMXK5AILACWDDDB4FYHBI/full/1.pdf

GoV - Government of Vietnam (2003) Decree No. 109/2003/ND-CP of the Government dated 23 September 2003 on the conservation and sustainable development of wetlands. Government of Vietnam, Hanoi.

GoV - Government of Vietnam (2005) National Report to the Fifth Session of the United Nations Forum on Forests: Vietnam. http://www.un.org/esa/forests/pdf/national_reports/ unff5/vietnam.pdf 
GoV - Government of Vietnam (2008a) Law on Biodiveristy. Government of Vietnam, Hanoi.

GoV - Government of Vietnam (2008b) Decree No. 01/2008/ND-CP of the Government dated 03 January 2008 defining the functions, tasks, powers and organizational structure of the Ministry of Agriculture and Rural Development. Government of Vietnam, Hanoi.

GoV - Government of Vietnam (2008c) Decree No. 116/2008/ND-CP of the Government dated 14 November 2008 defining the functions, tasks, powers and organizational structure of the Ministry of Planning and Investment. Government of Vietnam, Hanoi.

GoV - Government of Vietnam (2010) Decree No. 117/2010/ND-CP of the Government dated 24 December 2010 on the organization and management of the system of special use forests in Vietnam. Government of Vietnam, Hanoi.

GoV - Government of Vietnam (2013) Decree No. 76/2013/ND-CP of the Government dated 16 July 2013 defining the functions, tasks, powers and organizational structure of the Ministry of Culture, Sport and Tourism. Government of Vietnam, Hanoi.

GoV - Government of Vietnam (2014a) Decision No. 45/2014/QD-TTg of the Prime Minister dated 08 January 2014 on the approval of master plan for national biodiversity conservation to 2020, and a vision to 2030. Government of Vietnam, Hanoi.

GoV - Government of Vietnam (2014b) Decision No. 59/2014/QD-TTg of the Prime Minister dated 22 October 2014 on the approval of defining the functions, tasks, powers and organizational structure of Vietnam Administration of Forestry, Ministry of Agriculture and Rural Development. Government of Vietnam, Hanoi.

GoV - Government of Vietnam (2014c) Decision No. 1976/2014/QD-TTg of the Prime Minister dated 30 October 2014 on the approval of the planning for special use forest system to 2020, and a vision to 2030. Government of Vietnam, Hanoi.

GoV - Government of Vietnam (2015) Decision No. 1377/2015/QD-TTg of the Prime Minister dated 18 August 2015 on the establishment of Du Gia national park - Dong Van Stone Plateau, Ha Giang Province. Government of Vietnam, Hanoi.

GoV - Government of Vietnam (2017) Decree No. 36/2017/ND-CP of the Government dated 04 April 2017 defining the functions, tasks, powers and organizational structure of the Ministry of Natural Resources and Environment. Government of Vietnam, Hanoi.

GoV - Government of Vietnam, United Nations Development Program, Global Environmental Fund (2010) UNDP Project Document: Removing barriers hindering protected area management effectiveness in Viet Nam (PIMS 3965). http://www.vn.undp.org/content/ $\mathrm{dam} /$ vietnam/docs/Project\%20Documents/31386_Protected_Area_Prodoc110124x.pdf

Ha Thi Mung, Tuyet Hoa Nie Kdam (2008) Phân tích tình hình đầu tư tài chính cho hệ thống rừng dặc dụng Việt Nam [An analysis of financial investment status in the system of the special-use forests of Vietnam]. Forest Sector Development Project - Vietnam Conservation Fund, Forest Protected Department, Hanoi. [In Vietnamese]

Halpenny EA, Caissie LT (2003) Volunteering on nature conservation projects: Volunteer, experience, attitudes and values. Tourism Recreation Research 28(3): 25-33. https://doi.org /10.1080/02508281.2003.11081414

Haneji C, Amemiya T, Itoh K, Mochida Y, Hoang TTN, Pham VC (2014) Analysis of environmental stressors on ecosystems of Xuan Thuy National Park, Vietnam. Journal of Vietnamese Environment 5(1): 12-21. https://doi.org/10.13141/jve.vol5.no1.pp12-21 
Humphreys D (2016) Forest crimes and the international trade in illegally logged timber. In: Elliott L, Schaedla WH (Eds) Handbook of transnational environmental crime. Edward Elgar Publishing Limited,Cheltenham, UK, 168-189.

ICEM - International Centre for Environmental Management (2003) Vietnam national report on protected areas and development. Review of protected areas and development in the Lower Mekong River Region. International Centre for Environmental Management, Indooroopilly, Queensland, 1-60.

IUCN - International Union for Conservation of Nature, UNEP-WCMC - United Nations Environment Programme World Conservation Monitoring Centre (2017) The World Database on Protected Areas (WDPA), February 2017. UNEP-WCMC, Cambridge, UK. www.protectedplanet.net

Jiao Y (2016) Greater China and transnational environmental crime: understanding criminal networks and enforcement responses. In: Elliott L, Schaedla WH (Eds) Handbook of transnational environmental crime. Edward Elgar Publishing Limited, Cheltenham, UK, 255-275.

Khai HV, Yabe M (2014) Choice modeling: assessing the non-market environmental values of the biodiversity conservation of swamp forest in Vietnam. International Journal of Energy and Environmental Engineering 5: 77. https://doi.org/10.1007/s40095-014-0077-5

Le Quy Minh (2013) Bach Ma national park. In: Sunderland TCH, Sayer J, Hoang MH (Eds) Evidence-based conservation: lessons from the lower Mekong. CIFOR, Bogor, Indonesia, 39-49.

Leverington F, Hockings M, Pavese H, Costa KL, Courrau J (2008) Management effectiveness evaluation in protected areas - A global study. Supplementary report No.1: Overview of approaches and methodologies. The University of Queensland, Gatton, TNC, WWF, IUCNWCPA, Australia). https://cmsdata.iucn.org/downloads/methodologyreportdec08_final.pdf

Likert R (1932) A technique for the measurement of attitudes. Archives of Psychology, New York, 1-55.

Longley R (2016) Do the National Parks have enough money? https://www.thoughtco.com/ do-national-parks-have-enough-money-4084840

Luu Tuong Bach, Rawson BM (2011) Population assessment of the northern white-cheeked crested gibbon (Nomascus leucogenys) in Pu Mat National Park, Nghe An province. Conservation International/Fauna \& Flora International, Hanoi.

MARD - Ministry of Agriculture and Rural Development (2003) Conservation and management of wildlife in Vietnam. Forest Protection Department, Ministry of Agriculture and Rural Development, Hanoi.

McCuaig JM (2010) The regional integration of protected areas: A study of Canada's national parks. In: Weber S (Ed.) Rethinking protected areas in a changing world: Proceedings of the 2009 GWS Biennial Conference on Parks, Protected Areas, and Cultural Sites. The George Wright Society, Hancock, Michigan, 251-257. http://www.georgewright.org/0945mccuaig.pdf

McCrum-Gardner E (2008) Which is the correct statistical test to use? British Journal of Oral and Maxillofacial Surgery 46: 38-41. https://doi.org/10.1016/j.bjoms.2007.09.002

McElwee P (2004) You say illegal, I say legal: The relationship between 'illegal' logging and land tenure, poverty, and forest use rights in Vietnam. Journal of Sustainable Forestry 19(1-3): 97-135. https://doi.org/10.1300/J091v19n01_06 
Mishra HR (1994) South and Southeast Asia. In: McNeely JA, Harrison J, Dingwall P (Eds) Protecting nature: Regional reviews of protected areas. IUCN,Gland, and Cambridge, UK, 181-203.

Ministry of the Environment of Poland (2011) Finansowanie Parków Narodowych pod kontrolą [Financing of national parks under control]. https://archiwum.mos.gov.pl/kategoria/archiwum/7_archiwum/?data=2011-5 [In Polish]

MONRE - Ministry of Natural Resources and Environment (2004) Circular No. 18/2004/ TT-BTNMT of the Ministry of Natural Resources and Environment dated 23 August 2004 stipulating in the implementation of Decree No. 109/2003/ND-CP of the Government dated 23 September 2003 on the conservation and sustainable development of wetlands. Ministry of Natural Resources and Environment, Hanoi.

MONRE - Ministry of Natural Resources and Environment (2014) Vietnam's fifth national report to the United Nations Convention on biological diversity: Reporting period 20092013. Ministry of Natural Resources and Environment, Hanoi.

Nguyen Huynh Thuat, Yen Hoang Mai (2013) Cat Tien national park. In: Sunderland TCH, Sayer J, Hoang MH (Eds) Evidence-based conservation: lessons from the lower Mekong. CIFOR, Bogor, Indonesia, 17-28.

Nguyen KimDung, Bush S, Mol APJ (2012) Administrative co-management: The case of Special-Use Forest conservation in Vietnam. Environmental Management 51(3): 616-630. https://doi.org/10.1007/s00267-012-0012-6

Nguyen Manh Ha, Vu Van Dung, Nguyen Van Song, Hoang Van Thang, Nguyen Huu Dung, Pham Ngoc Tuan, Than Thi Hoa, Doan Canh (2007) Report on the review of Vietnam's wildlife trade policy. CRES/FPD/UNEP/CITES/IUED, Hanoi.

Nguyen MH (2009) The status of Vulnerable gaur Bos gaurus and Endangered banteng Bos javanicus in Ea So Nature Reserve and Yok Don and Cat Tien National Parks, Vietnam. Oryx 43(1): 129-135. https://doi.org/10.1017/S0030605307000440

Nguyen Van Song (2008) Wildlife trading in Vietnam: Situation, causes, and solutions. The Journal of Environment \& Development 17(2): 145-165. https://doi.org/10.1177/1070496508316220

Nuwer R, Bell D (2013) Identifying and quantifying the threats to biodiversity in the U Minh peat swamp forests of the Mekong Delta, Vietnam. Oryx 48(1): 88-94. https://doi.org/10.1017/ S0030605312000865

PARC Project (2006) Policy Brief: Building Viet Nam's national protected areas system - policy and institutional innovations required for progress. Creating Protected Areas for Resource Conservation using Landscape Ecology (PARC) Project VIE/95/G31\&031, FPD/UNOPS/ UNDP/IUCN, Hanoi.

Pham TT, Bennet K, Vu TP, Brunner J, Le ND, Nguyen DT (2013) Payments for forest environmental services in Vietnam: From policy to practice. Occasional Paper 93. CIFOR (Bogor, Indonesia): 1-78.

Rambaldi G, Bugna S, Geiger M (2001) Review of the protected area system of Vietnam. ASEAN Biodiversity 1(4): 43-51.

Schägner JP, Brander L, Maes J, Paracchini ML, Hartje V (2016) Mapping recreational visits and values of European National Parks by combining statistical modelling and unit value transfer. Journal for Nature Conservation 31: 71-84. https://doi.org/10.1016/j.jnc.2016.03.001 
Spoelder P, Lockwood M, Cowell S, Gregerson P, Henchman A (2015) Planning. In: Worboys GL, Lockwood M, Kothari A, Feary S, Pulsford I (Eds) Protected Area Governance and Management. ANU Press, Canberra, 381-412.

Steven R, Pickering C, Castley JG (2011) A review of the impacts of nature based recreation on birds. Journal of Environmental Management 92: 2287-2294. https://doi.org/10.1016/j. jenvman.2011.05.005

Thomas L, Middleton J (2003) Guidelines for management planning of protected areas. IUCN, Gland, Switzerland, and Cambridge,UK, 1-79.

To Xuan Phuc (2009) Why did the forest conservation policy fail in the Vietnamese uplands? Forest conflicts in Ba Vi National Park in Northern Region. International Journal of Environmental Studies 66(1): 59-68. https://doi.org/10.1080/00207230902759988

Trædal LT, Vedeld PO, Pétursson JG (2015) Analyzing the transformations of forest PES in Vietnam: Implications for REDD+. Forest Policy and Economics 62: 109-117. https:// doi.org/10.1016/j.forpol.2015.11.001

USAID - United States Agency for International Development (2013) Vietnam tropical forest and biodiversity assessment. Sun Mountain International and The Cadmus Group, Inc., Quito, Ecuador.

Vietnam News (2016) Highway project causes diversity loss for forest. http://vietnamnews.vn/ society/281328/highway-project-causes-diversity-loss-for-forest.html

VNFOREST - Vietnam Administration of Forestry (2014) Báo cáo quy hoạch hệ thống rừng đặc dụng cả nước đến năm 2020 [Report on the national planning of the system of Special Use Forests until 2020]. Vietnam Administration of Forestry, Ministry of Agriculture and Rural Development, Hanoi. [In Vietnamese]

Vo Quy, Nguyen Ba Thu, Ha Dinh Duc, Le Van Tac (1996) Cuc Phuong national park. Agricultural Publishing House, Hanoi, 1-57.

Wearing S (2001) Volunteer tourism: Experiences that make a difference. CABI Publishing, London, 1-205.

Worboys GL, Trzyna T (2015) Managing protected areas. In: Worboys GL, Lockwood M, Kothari A, Feary S, Pulsford I (Eds) Protected Area Governance and Management. ANU Press, Canberra, 207-250. 


\section{Appendix I}

Questionnaire for the survey on conservation and management of the national park.

\section{General information about the national park}

1. Name and location of the national park

a) Name of the national park: ...........................

b) Location: ................. District....................Province..........

2. Who is responsible for the administration of the national park?

(Please mark $(\sqrt{ })$ only one appropriate box)

$\square$ Provincial People’s Committee (Please specify

$\square$ Vietnam Administration of Forestry, Ministry of Agriculture and Rural Development

\section{Area and designations}

3. What is the area of the national park and its buffer zones?

a) ............... ha of the total area of the park, including ..........ha of marine area

b) ...............ha of buffer zones, of which marine area covers ...........ha

4. Other designations of the national park,

a) Was the national park or national park areas recognized/designated regional/international agreements? (Please mark ( $\sqrt{ }$ ) only one appropriate box)

$\square \mathrm{NO}$

$\square$ YES, Go to b)

b) Please select regional/international designations?

(You may choose more than one by marking $(\sqrt{ })$ appropriate boxes)

$\square$ UNESCO Natural World Heritage Sites

$\square$ UNESCO Biosphere Reserves

$\square$ Wetlands of International Importance (Ramsar Sites)

$\square$ Others (Please specify..................................)

$\square$ ASEAN Heritage

Parks

$\square$ Marine Protected

Areas

\section{Management Plan}

5. Concerning the national park management plan,

a) Which updating status of the management plan has been applied for current management of the national park?

(Please mark ( $\sqrt{ }$ ) only one appropriate box)

$\square$ Outdated Management Plan

$\square$ Updated Management Plan

$\square$ Management Plan updated by more management tools. Go to $b$ )

b) Please select other management tools as flows:

(You may choose more than one by marking $(\sqrt{ })$ appropriate boxes)

$\square$ Community based forest management

$\square$ Multiple - use forest management plan

$\square$ Environmental impact assessment

$\square$ Regulations for research activities in the national park

$\square$ Sustainable eco-tourism/tourism development plan

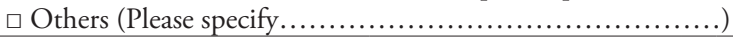

6. In the current context of socio-economic development,

a) Does the management plan provide a sufficient protection in relation to developmental plan(s) of local communities and region(s)?

(Please mark $(\sqrt{ })$ only one appropriate box)

\section{$\square$ YES}

$\square$ NO. Go to $b$ )

b) If $\mathrm{NO}$, it is a result of

(You may choose more than one by marking $(\sqrt{ })$ appropriate boxes) 
$\square$ Lack of constantly updated debates

$\square$ Lack of coordination among agencies and communities that have a bearing on the park

$\square$ Confusing, conflicting and overlapping institutional and legal frameworks

$\square$ Non-existence of mechanisms and strategies to engage communities in the conservation of the park

$\square$ Others (Please specify.....

\section{Financial sources}

7. Concerning financial sources of the total funding for the national park in 2016,

a) What is the percentage of financial sources of the total funding?

(You may choose more than one by marking $(\sqrt{ })$ appropriate boxes)

Financial sources

\begin{tabular}{|l|l|l} 
& Percent & $\begin{array}{l}\text { If possible, please } \\
\text { specify in VND } \\
\text { million }\end{array}$ \\
\hline & & \\
\hline & & \\
\hline & & \\
\hline & 100 & \\
\hline
\end{tabular}

$\square$ The state budget

$\square$ The provincial budget

$\square$ Supports from domestic organizations

(Please specify .................................)

$\square$ Supports from international organizations

(Please specify. ...

$\square$ Funds of conservation programs

(Please specify.....

$\square$ Revenues from forest environmental services

$\square$ Revenues from tourism activities

$\square$ Others

(Please specify.

Total

b) What is the percentage of the total funding for the national park invested in conservation activities in 2016?

(Please mark ( $\sqrt{ }$ ) only one appropriate box)

\begin{tabular}{l|l|l|l}
\hline$\square 10$ & $\square 20$ & $\square 30$ & $\square 40$ \\
\hline$\square 50$ & $\square 60$ & $\square 70$ & $\square 80$ \\
\hline
\end{tabular}

$\square$ Other (Please specify ...........\%)

\section{Cooperative activities}

8. Have the national park cooperated with scientific institutes in conservation and national park management?

(Please mark $(\sqrt{ })$ only one appropriate box)

$\square \mathrm{NO}$

$\square$ YES. Go to $b$ ), and $c$ )

b) If YES, which scientific institutes?

(You may choose more than one by marking $(\sqrt{ })$ appropriate boxes)

$\square$ Vietnamese Academy of Forest Sciences

$\square$ Vietnam Academy of Science and Technology

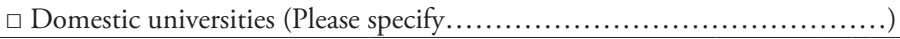

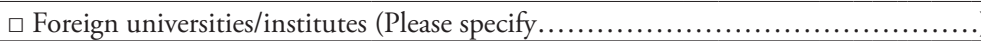

$\square$ NGOs (Please specify ..............................)

$\square$ Others (Please specify ................................)

c) What kind of cooperative activities have been cooperated with scientific institutes in the national park? (You may choose more than one by marking $(\sqrt{ })$ appropriate boxes)

\begin{tabular}{l|l}
\hline$\square$ Species monitoring & $\square$ Education and training \\
\hline$\square$ Biodiversity conservation & $\square$ Forestry management \\
\hline$\square$ Eco-tourism management and development & $\square$ Cultural heritage conservation \\
\hline $\begin{array}{l}\square \text { Socio-economic development in buffer zone of the national park } \\
\square \text { Others (Please specify...................................) }\end{array}$
\end{tabular}


9. For conservation programmes/projects in the national park,

a) Has the national park involved schools, volunteers in various projects?

(Please mark $(\sqrt{ })$ only one appropriate box)

$\square \mathrm{NO}$

$\square$ YES. Go to $b$ )

b) If YES, please specify in which?

(You may choose more than one by marking $(\sqrt{ })$ appropriate boxes)

$\square$ Environmental education and training/Education services

$\square$ Help with practical conservation tasks

$\square$ Survey work and short work - experience placements

$\square$ Others (Please specify ...............................)

10. How many academic papers were published by park's staff in the previous 5 years, including co-authors of papers?

(Please mark ( $\sqrt{ }$ ) only one appropriate box)

\begin{tabular}{l|l|l|l}
\hline Subject area of & Journals & Books & $\begin{array}{l}\text { Other papers } \\
\text { Please } \\
\text { specify...........) }\end{array}$ \\
\hline$\square$ Biology, ecology, nature conservation & & & \\
\hline$\square$ Economics, business management, law & & & \\
\hline$\square$ Forestry, agriculture, fishery & & & \\
\hline$\square$ Tourism & & & \\
\hline$\square$ Geography, geology, geomorphology & & & \\
\hline$\square$ Archeology, history, cultural heritage conservation & & & \\
\hline$\square$ Others (Please specify.............) & & & \\
\hline
\end{tabular}

\section{Causes of limited management capacity}

11. Please tell us how you feel about the following statement concerning causes of limited management capacity of the national park towards conservation and natural resource management?

(For each statement, please circle the number that is appropriate under one of the five categories which applies $S D$ Strongly disagree, D - Disagree, $N$ - Neutral, A - Agree, SA - Strongly agree)

\begin{tabular}{|c|c|c|c|c|c|}
\hline & SD & $\mathrm{D}$ & $\mathrm{N}$ & A & SA \\
\hline $\begin{array}{l}\text { a) The park suffers from a lack of funding for conservation activities and national } \\
\text { park management }\end{array}$ & 1 & 2 & 3 & 4 & 5 \\
\hline $\begin{array}{l}\text { b) The park suffers from a lack of enforcement authority for national park } \\
\text { management boards }\end{array}$ & 1 & 2 & 3 & 4 & 5 \\
\hline c) There are overlapping and conflicting institutional mandates & 1 & 2 & 3 & 4 & 5 \\
\hline d) The park has focused on hard infrastructure instead of conservation activities & 1 & 2 & 3 & 4 & 5 \\
\hline e) The park suffers from a lack of limited human and institutional capacity & 1 & 2 & 3 & 4 & 5 \\
\hline $\begin{array}{l}\text { f) There is the population growth and resource use pressure within and around the } \\
\text { park. }\end{array}$ & 1 & 2 & 3 & 4 & 5 \\
\hline g) There is under construction of infrastructure within protected areas & 1 & 2 & 3 & & 5 \\
\hline ) There is suffering from land use conflict/land grab & 1 & 2 & 3 & 4 & 5 \\
\hline
\end{tabular}

\section{Threats to natural resources}

12. Please tell us how you feel about the following statement concerning current threats to biodiversity and natural resources in the national park?

(For each statement, please circle the number that is appropriate under one of the five categories which applies $S D$ -

Strongly disagree, D - Disagree, N-Neutral, A - Agree, SA - Strongly agree)

\begin{tabular}{l|l|l|l|l|l}
\hline & SD & D & N & A & SA \\
\hline There is illegal hunting, trapping, poaching, fishing & 1 & 2 & 3 & 4 & 5 \\
\hline There is illegal trade in wildlife & 1 & 2 & 3 & 4 & 5 \\
\hline There is illegal logging, firewood collecting & 1 & 2 & 3 & 4 & 5 \\
\hline Illegal non-timber forest product collection is present & 1 & 2 & 3 & 4 & 5 \\
\hline Mineral exploitation or quarrying is present & 1 & 2 & 3 & 4 & 5 \\
\hline
\end{tabular}




\begin{tabular}{|c|c|c|c|c|c|}
\hline There are hydroelectric dam/projects, dams & 1 & 2 & 3 & 4 & 5 \\
\hline Dykes and canals are under development & 1 & 2 & 3 & 4 & 5 \\
\hline $\begin{array}{l}\text { Existing and planned routes (roads, motorways, train treks) cross the park or are } \\
\text { situated in its vicinity }\end{array}$ & 1 & 2 & 3 & 4 & 5 \\
\hline There is pollution (water, soil, air, noise pollution) & 1 & 2 & 3 & 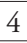 & 5 \\
\hline There is land use change & 1 & 2 & 3 & 4 & 5 \\
\hline $\begin{array}{l}\text { There is the tourism development (overlap intensive tourism and related pressure to } \\
\text { invest in tourist infrastructure in the national park and its vicinity) }\end{array}$ & 1 & 2 & J & 4 & \\
\hline
\end{tabular}

\section{The national park staff}

13. How many employees work in the national park, according to level of education and educational background?

(You may choose more than one by marking $(\sqrt{ })$ appropriate boxes)

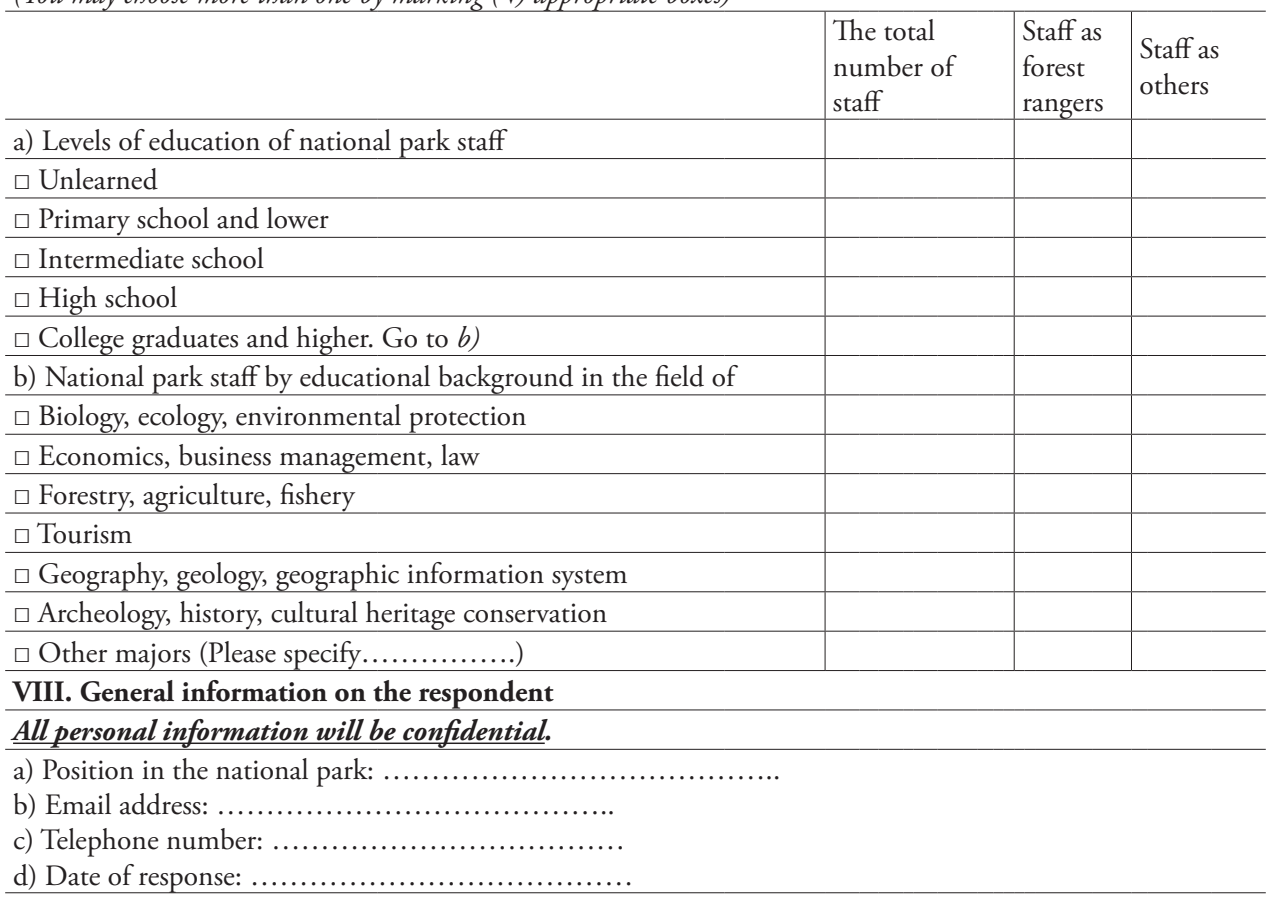

If you wish to provide feedback for improvement of this survey, please add any further comments/ suggestions below.

\section{Appendix 2}

Questions for interviews with members of national park management boards

1. What do you think about the development of ecotourism/nature-based tourism in the national park as alternative livelihoods of local residents who live within and around the park?

2. What are your opinions about trends of financial sources on funding for the park as well as conservation activities and natural resource management?

3. What do you think about the roles of the park's own fundraising (e.g. revenues from tourism activities) as well as its financial autonomy in the contribution to conservation and management of the park? 